\title{
Erratum to: Reducing the Incidence of Hematomas in Cervicofacial Rhytidectomy: New External Quilting Sutures and Other Ancillary Procedures
}

João Cabas Neto • Dario Ernesto Rodriguez Fernandez • Murilo Boles

Published online: 28 August 2013

(c) Springer Science+Business Media New York and International Society of Aesthetic Plastic Surgery 2013

Erratum to: Aesth Plast Surg

DOI 10.1007/s00266-013-0084-6

The category of this article should be changed from

"Original Article" to "Innovative Techniques".

The online version of the original article can be found under doi:10.1007/s00266-013-0084-6.

J. C. Neto $(\bowtie) \cdot$ D. E. Rodriguez Fernandez $\cdot$ M. Boles Brazilian Society of Plastic Surgery, Clinica Aleixo Neto, Rua Aleixo Netto, 1666, Praia do Canto, Vitória, ES CEP 29055-260, Brazil

e-mail: cabas@uol.com.br 